The most widely read and highly cited peer-reviewed neurology journal The Official Journal of the American Academy of Neurology

Neurology Publish Ahead of Print

DOI: 10.1212/WNL.0000000000013321

\title{
Teaching NeuroImage: Carotid Web: A Thrombogenic Nest Not to Miss
}

\begin{abstract}
Author(s):
Vasileios Rafailidis, $\mathrm{MD}, \mathrm{PhD}^{1}$; Ioanna Koutroulou, $\mathrm{MD}, \mathrm{PhD}^{2}$; Elizabeth Psoma, $\mathrm{MD}, \mathrm{PhD}^{1}$; Konstantinos Kouskouras, $\mathrm{MD}, \mathrm{PhD}^{1}$; Maria Alexandratou, $\mathrm{MD}^{1}$; Panagiotis Stoiloudis, $\mathrm{MD}^{2}$; Panos Prassopoulos, $\mathrm{MD}, \mathrm{PhD}^{1}$; Nikolaos Grigoriadis, $\mathrm{MD}, \mathrm{PhD}^{2}$; Theodoros Karapanayiotides, $\mathrm{MD}, \mathrm{PhD}^{2}$

Corresponding Author:

Theodoros Karapanayiotides

tkarapanayiotides@yahoo.gr
\end{abstract}

Neurology ${ }^{\circledR}$ Published Ahead of Print articles have been peer reviewed and accepted for publication. This manuscript will be published in its final form after copyediting, page composition, and review of proofs. Errors that could affect the content may be corrected during these processes. 
Affiliation Information for All Authors: 1. Department of Radiology, Aristotle University of Thessaloniki, School of Medicine, AHEPA University Hospital, Thessaloniki, Greece; 2. 2nd Department of Neurology, Aristotle University of Thessaloniki, School of Medicine, AHEPA University Hospital, Thessaloniki, Greece

\section{Contributions:}

Vasileios Rafailidis: Drafting/revision of the manuscript for content, including medical writing for content; Major role in the acquisition of data; Analysis or interpretation of data

Ioanna Koutroulou: Drafting/revision of the manuscript for content, including medical writing for content; Major role in the acquisition of data; Analysis or interpretation of data

Elizabeth Psoma: Major role in the acquisition of data; Analysis or interpretation of data

Konstantinos Kouskouras: Major role in the acquisition of data; Analysis or interpretation of data Maria Alexandratou: Major role in the acquisition of data

Panagiotis Stoiloudis: Major role in the acquisition of data; Analysis or interpretation of data

Panos Prassopoulos: Drafting/revision of the manuscript for content, including medical writing for content; Analysis or interpretation of data

Nikolaos Grigoriadis: Drafting/revision of the manuscript for content, including medical writing for content

Theodoros Karapanayiotides: Drafting/revision of the manuscript for content, including medical writing for content; Major role in the acquisition of data; Study concept or design; Analysis or interpretation of data

Number of characters in title: 44

Abstract Word count: 0

Word count of main text: 100

References: 2

Figures: 2

Tables: 0

Neuroimage Legend Count: 104

Supplemental: Consent-to-disclose Form

Search Terms: [ 2 ] All Cerebrovascular disease/Stroke, [ 11 ] Stroke in young adults, [ 119 ] CT, [ 124 ] Ultrasound

Study Funding: The authors report no targeted funding

Disclosures: The authors report no disclosures relevant to the manuscript. 
A 61-year-old woman suffered a territorial infarction due to right middle cerebral artery occlusion. CT angiography and ultrasonography showed an ipsilateral carotid web with a small superimposed thrombus (Figures 1-2). After two weeks on enoxaparin and aspirin the thrombus resolved completely and the patient underwent uncomplicated carotid stenting, in the absence of other stroke causes. Carotid web, an intimal variant of fibromuscular dysplasia, is an underestimated cause of cryptogenic stroke, notorious for being missed or taken for atheroma by ultrasonography ${ }^{1}$. It may have a high rate of stroke recurrence under antiplatelets owing to thrombus nesting along its blood-stagnation-causing downstream surface. $^{2}$

[AZ 12.28.2021] 178088 Teaching Slides -- http://links.lww.com/WNL/B755

References

1. Coutinho JM, Derkatch S, Potvin ARJ, et al. Carotid artery web and ischemic stroke. Neurology 2017;88(1):65-69.

2. Kim SJ, Nogueira RG, Haussen DC. Current Understanding and Gaps in Research of Carotid Webs in Ischemic Strokes. JAMA Neurol 2019;76(3):355-361. 
Figure 1. Right carotid CT angiography upon admission and after antithrombotic treatment.

Oblique sagittal thin-slice reformatted (A, D), volume-rendered (B, E) and intraluminal volume-rendered images $(\mathrm{C}, \mathrm{F})$ showing the diaphragm-like web attached to the posterior wall of the carotid bulb (arrows). A beak-like protuberance on the cephalad web surface corresponds to in situ thrombus (A-C, arrowheads), missing at follow-up (D-F) and confirming thrombus resorption.

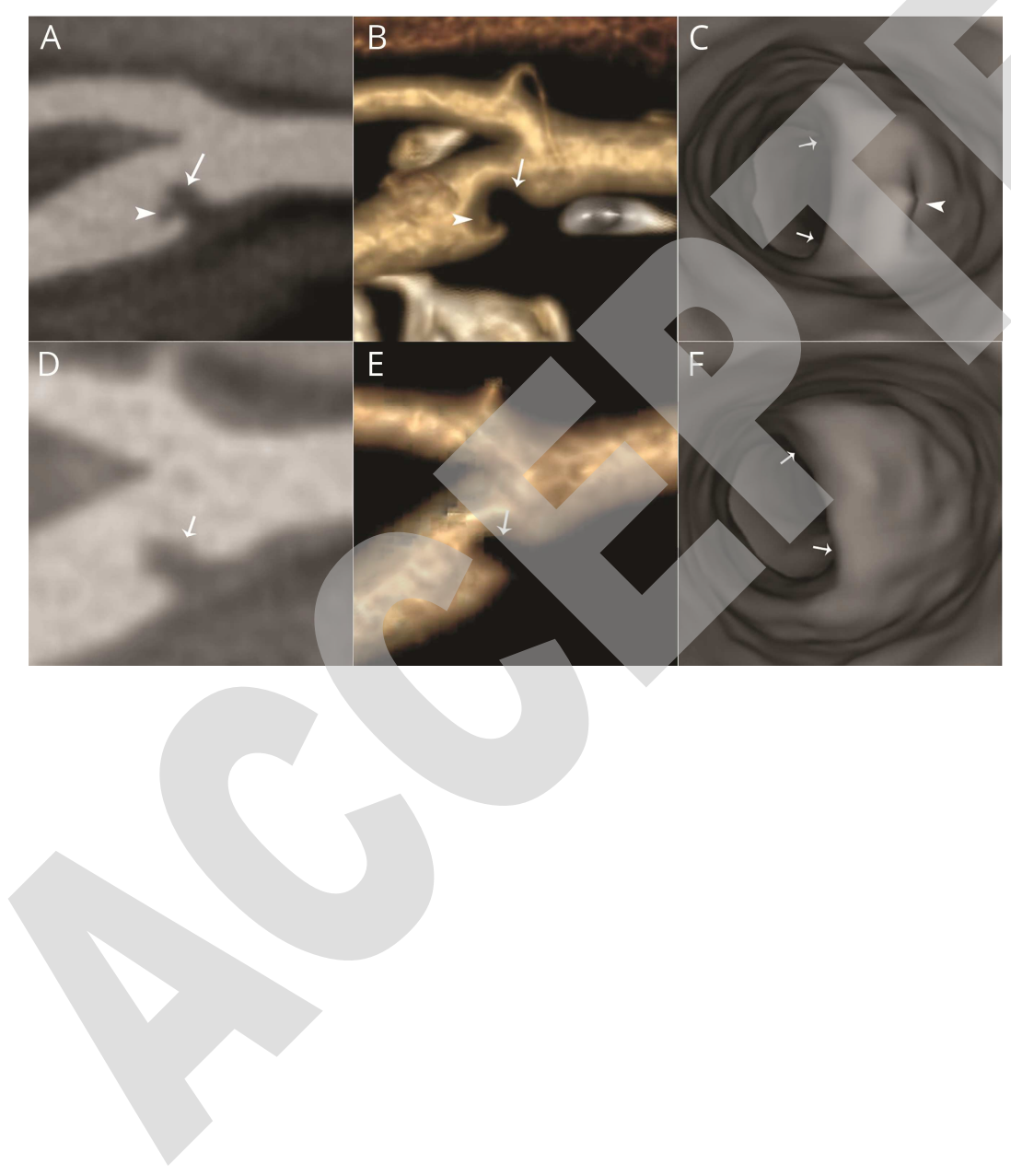


Figure 2. Right carotid ultrasonography upon admission

Longitudinal B-mode (A) and Sonovue-enhanced image (B) showing the echogenic and irregular web protruding into the lumen (long arrows) along with the superimposed distal web-surface thrombus (short arrows). Compare to the "beak" in Figure 1, A-C. On powerDoppler flow imaging the web mimics the appearance of a non-stenosing isoechogenic atheroma (C, arrowheads).

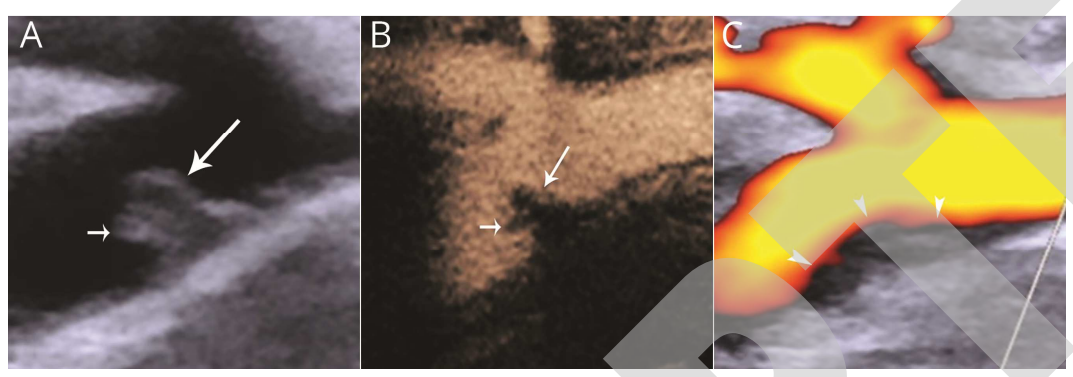




\section{Neurology}

\section{Teaching NeuroImage: Carotid Web: A Thrombogenic Nest Not to Miss Vasileios Rafailidis, Ioanna Koutroulou, Elizabeth Psoma, et al. \\ Neurology published online January 11, 2022 \\ DOI 10.1212/WNL.0000000000013321}

This information is current as of January 11, 2022

\section{Updated Information \& Services}

Subspecialty Collections

Permissions \& Licensing

Reprints including high resolution figures, can be found at:

http://n.neurology.org/content/early/2022/01/11/WNL.0000000000013321. citation.full

This article, along with others on similar topics, appears in the following collection(s):

All Cerebrovascular disease/Stroke

http://n.neurology.org/cgi/collection/all_cerebrovascular_disease_stroke CT

http://n.neurology.org/cgi/collection/ct

Stroke in young adults

http://n.neurology.org/cgi/collection/stroke_in_young_adults

Ultrasound

http://n.neurology.org/cgi/collection/ultrasound

Information about reproducing this article in parts (figures,tables) or in its entirety can be found online at:

http://www.neurology.org/about/about_the_journal\#permissions

Information about ordering reprints can be found online:

http://n.neurology.org/subscribers/advertise

Neurology ${ }^{\circledR}$ is the official journal of the American Academy of Neurology. Published continuously since 1951, it is now a weekly with 48 issues per year. Copyright (C) 2022 American Academy of Neurology. All rights reserved. Print ISSN: 0028-3878. Online ISSN: 1526-632X.

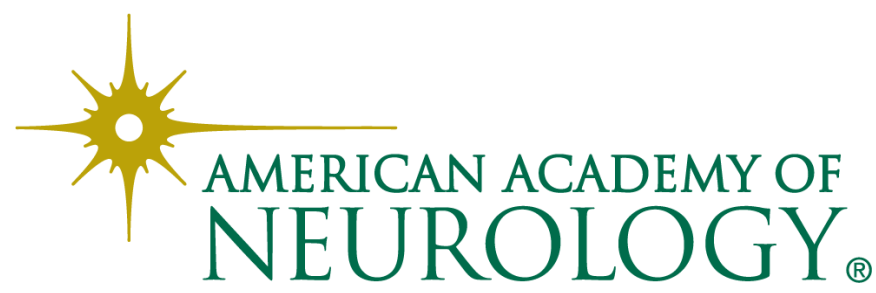

